\title{
Russia of Power
}

Helsingfors: Puolustusministeriö/Försvarsministeriet 2019

182 sider. ISBN 9789516630659

Anmeldt av Ingerid M. Opdahl [førsteamanuensis, Institutt for forsvarsstudier, Forsvarets høgskole, Oslo, iopdahl@fhs.mil.no]

Russia of Power er den tredje rapporten i en serie som tar for seg Russlands utvikling, særlig vinklet mot Russland som internasjonal sikkerhetspolitisk aktør. Som de forrige rapportene, Russia of Challenges (2008) og Russia of Transformations (2012), er også denne bestilt av Finlands forsvarsdepartement og er skrevet av et bredt sammensatt team av mer enn 40 finske forskere og eksperter. Denne gangen er også Finlands utenriks- og innenriksdepartement med som oppdragsgivere. Rapportens målsetting er å øke oppmerksomheten rundt og forståelsen av Russland, og i innledningen erklæres det at det foreligger et behov for kritisk analyse. Når man leser, er det tydelig at bredden i analysen er særlig godt ivaretatt. Rapporten bygger på et rikt og oppdatert tilfang av kilder, og teksten er en systematisk gjennomgang av ulike aspekter ved tematikken. Det er også lagt ned en betydelig innsats underveis for å sammenstille, syntetisere og ivareta helheten, slik at leseren får nettopp en kritisk innføring i Russlands utenrikspolitikk, forsvar og innenrikspolitikk. I slutten av rapporten pekes det også fremover.

Rapporten kan anses som en kraftprestasjon, en tour de force, fra det russlandsmiljøet i Norden som utmerker seg med særlig bredde i fagfeltet. I vurderingene av konsekvenser og implikasjoner for Finland får leseren også et innblikk i de grunnleggende sidene ved finsk sikkerhetspolitikk.

Rapporten tar først for seg den russiske utenrikspolitikken, deretter følger to kapitler om forsvar og forsvarsindustri, et kapittel om Russlands indre utvikling og til sist et avsluttende kapittel med tittelen «Russia's future: drivers for change». For hvert kapittel får vi vite hvem som har skrevet eller koordinert arbeidet, og hvem (mange av) deltagerne er. Unntaket er det siste kapitlet, der forfatteren oppgis og det opplyses om at mange av prosjektets deltagere har bidratt.

Kapitlet om utenrikspolitikk begynner med en ryddig gjennomgang av utenrikspolitikkens premisser, der man kort tar for seg beslutningsprosess og dokumenter, interesser og trusler samt begrepet «interessesfære». Bildet de finske forskerne beskriver er velkjent og vil ikke overraske nordiske fagfeller. Det er likevel interessant å se deres oversiktlige analyse av helheten i Russlands strategiske dokumenter etter 2014, der trusler mot nasjonal sikkerhet nå inkluderer direkte og indirekte trusler mot landets 
interesser, ikke kun en snevrere definert nasjonal integritet, suverenitet og forsvarsevne. Av særlig interesse er selvsagt implikasjonene for Finland, som lett kan relateres til resten av det nordiske bildet. Det er verdt å merke seg vurderingen av russisk påvirkning på Finlands sikkerhetspolitiske debatt og beslutningsprosess. Det hevdes at Russlands offisielle - og positive - vektlegging av et godt naboskap suppleres, uformelt og indirekte, med at Finland ikke kan ta det for gitt at det gode naboskapet vedvarer, med mindre finske beslutningstagere tar «ansvarlige» beslutninger (s. 40).

Dette siste gjelder i høyeste grad Finlands militære samarbeid med Nato, slik det også fremgår i analysen av det russiske forsvaret. På dette punktet har de russiske uttalelsene vært negative på både generalstabs- og ministernivå. I rapporten påpekes det at Finland, med en erklært politikk som utelukker Nato-medlemskap (fra 2011), har begrenset sitt sikkerhetspolitiske handlingsrom på en måte som gagner Russland (s. 56). Det minnes også om at ønsket om å vektlegge hensynet til Russlands interesser ofte fremsettes slik at Russlands bidrag til å destabilisere internasjonal sikkerhet forsvinner ut av debatten. Det er, så vidt denne leseren kan se, det nærmeste rapportens forfattere beveger seg en smule i retning av å gi råd om policy.

Rapporten inneholder en oversiktlig og bred fremstilling av Russlands militære kapasiteter, fra våpen inkludert elektronisk krigføring og informasjonsteknologi til private militære selskap og spesialstyrker. I denne delen er enkelte underavsnitt forholdsvis knappe, noe som reflekterer at kildene er til dels få. Det samme gjelder kapitlet om forsvarsindustrien, som heldigvis ser industriens utfordringer i sammenheng med Russlands økonomiske utvikling. Dermed unngår man at gjennomgangen blir overfladisk.

Samfunnsutviklingen i Russland analyseres i et langt og interessant kapittel, der både den topptunge beslutningsprosessen, kilder til sosial ustabilitet, økonomi og demografi behandles med autoritet. Fraværet av en sosialt orientert sosialpolitikk skaper mange problemer i samfunnet og dermed også for regimets stabilitet. Særlig slående er mangelen på helhetlig, systemisk reform av økonomi og forvaltning. De sektorspesifikke utviklingsprogrammene, som etter 2000 har blitt så viktige i russisk forvaltning, får dermed liten reell betydning for samfunnsutviklingen. Når dette ses i sammenheng med fordelene som eksisterer for de som sitter nærmest toppen, får man en klar forståelse av hvorfor Russland har få utsikter til økonomisk vekst $i$ årene som kommer.

Sammenlignet med tidligere rapporter har prosjektet bak Russia of Power lagt mer vekt på å utarbeide samlede helhetsscenarioer som peker fremover fra arbeidet. Det inkluderer et raskt blikk på russiske eksperters behandling av globale trender. Dette er et interessant grep, men det kunne vært gjort mer ut av. Hvem leser de russiske artiklene som er oppsummert her? Får de gjennomslag? Hvordan reflekterer de den russiske offentlighetens manglende åpenhet og vilje til å debattere egne utfordringer? Nå står avsnittet uten kontekst, og innholdet blir i liten grad problematisert. Dette er et særlig savn i en slik rapport, ettersom den (antar jeg) også retter seg mot dem som har ikke har nok bakgrunnskunnskap til å lese mellom linjene. 
Deretter tar man for seg globale trender og, ikke minst, såkalte svake signaler, definert som fenomener og hendelser som hver for seg synes av liten betydning, men som kan komme til å påvirke utviklingen om de forsterkes. Her gir avslutningskapitlet et særlig verdifullt bidrag til vår forståelse av Russland. Scenarioene, som skal si noe om mulige retninger for Russland i drøye to tiår fremover, er nøkterne til scenarioer å være. Det er mulig å se for seg hvordan de kan utspille seg under ulike forutsetninger, også der forfatterne påpeker at sannsynligheten er lav. Scenarioer er ikke alltid like interessante, men her har de en naturlig plass.

Med rapporter av denne typen er det man ser, altså det som loves i forordet, det man får: solid analyse og grunnlag for bedre forståelse av en viktig internasjonal aktør. Forhåpentligvis vil den bli lest av mange, også utenfor dette tidsskriftets faste leserskare. 